\title{
Differentiation of Staphylococcus aureus and Staphylococcus epidermidis by PCR for the fibrinogen binding protein gene
}

\author{
R. Sunagar, ${ }^{*}$ S. N. Deore, ${ }^{*}$ P. V. Deshpande,† A. Rizwan,† A. D. Sannejal,† S. Sundareshan, † D. B. Rawool, ${ }^{*}$ \\ S. B. Barbuddhe,‡ M. K. Jhala,§ A. S. Bannalikar,\# D. M. Mugalikar,II V. J. Kumari,ף K. Dhanalakshmi,ף \\ Y. N. Reddy, đ P. P. Rao, ${ }^{*}$ C. Babra, ${ }^{* *}$ J. G. Tiwari,, ${ }^{* *}$ T. K. Mukkur, ${ }^{* *}$ P. Costantino, ${ }^{* *}$ J. D. Wetherall, ${ }^{* *}$ \\ S. Isloor, † and N. R. Hegde*1 \\ *Ella Foundation, Genome Valley, Turkapally, Shameerpet Mandal, Hyderabad 500078, India \\ †Veterinary College, Karnataka Veterinary, Animal and Fisheries Sciences University, Bengaluru 560024, India \\ †ICAR Research Complex for Goa, Ela, Old Goa 403402, India \\ §Veterinary College, Anand Agricultural University, Anand 388001, India \\ \#KNP College of Veterinary Sciences, Maharashtra Animal and Fishery Sciences University, Shirval, India \\ $\|$ Bombay Veterinary College, Maharashtra Animal and Fishery Sciences University, Mumbai, India \\ ICollege of Veterinary Science, Sri Venkateswara Veterinary University, Hyderabad, India \\ ${ }^{*}$ School of Biomedical Sciences, Curtin Health Innovation Research Institute, Curtin University, Perth, Australia
}

\section{ABSTRACT}

Mastitis is one of the most common and burdensome diseases afflicting dairy animals. Among other causes of mastitis, staphylococci are frequently associated with clinical and subclinical mastitis. Although Staphylococcus aureus is the predominant species involved, Staphylococcus epidermidis and other coagulase-negative staphylococci are increasingly being isolated from cases of bovine mastitis. Although Staph. aureus and Staph. epidermidis can be easily differentiated based on their biochemical properties, such phenotypic identification is time consuming and laborious. This study aimed to rapidly identify Staph. aureus and Staph. epidermidis. Accordingly, a multiplex PCR was developed and we found that a single gene encoding the adhesin fibrinogen binding protein could be used to identify and differentiate the two species. Consequently, a multiplex reaction combining a triplex PCR for Staph. aureus and a duplex PCR for Staph. epidermidis was standardized, first using bacterial cultures and then with pasteurized milk spiked with live organisms or DNA extracted from the organisms. The test could specifically detect Staph. aureus and Staph. epidermidis even in the presence of a dozen other organisms. The limit of detection for detecting Staph. aureus and Staph. epidermidis separately was 10 to $100 \mathrm{cfu} / \mathrm{mL}$ for simplex PCR and $10^{4} \mathrm{cfu} / \mathrm{mL}$ for multiplex PCR. Conversely, the limit was $10^{6} \mathrm{cfu} /$ $\mathrm{mL}$ by multiplex PCR for simultaneous detection of both the organisms when spiked into culture medium or pasteurized milk. Overnight enrichment enhanced the assay sensitivity 100-fold. The assay had a high

Received June 22, 2012.

Accepted January 8, 2013.

${ }^{1}$ Corresponding author: hegden@ellafoundation.org diagnostic sensitivity and specificity. The application of the test was verified on 602 field isolates of staphylococci that had been characterized earlier by phenotypic methods. Importantly, 25 coagulase-negative isolates were identified as Staph. aureus by the multiplex PCR. The test could be adapted for use in clinical diagnostic laboratories.

Key words: bovine mastitis, staphylococci, detection and differentiation, multiplex PCR

\section{INTRODUCTION}

Bovine mastitis is one of the most important diseases affecting dairy industry. The disease costs around Rs 72 billion (approximately $\$ 1.4$ billion) per year (Bansal and Gupta, 2009) to India, where the livestock sector contributes 5 to $6 \%$ to the gross domestic product. Speedy diagnosis of mastitis, particularly that of subclinical cases, and rapid identification of the causative agent(s) are crucial for designing appropriate therapy and management to control mastitis.

Bacteria account for most IMI. During mastitis, multiple pathogens, variable shedding, inhibitors from both the host and the microbes, antibiotic residues, presence of inflammatory cells, and the persistence of inflammation even after the clearance of bacteria produce a dynamic state of udder infection and inflammation (Pyörälä and Mattila, 1987; Sears et al., 1990; Dinsmore et al., 1992; Suojala et al., 2008; Taponen et al., 2009; Koskinen et al., 2010). These and other factors, such as unfavorable conditions during transport of samples and during enrichment (Dinsmore et al., 1992; Koskinen et al., 2010), incubation or freezing before culturing, inoculum volume, and enrichment conditions (Schukken et al., 1989; Dinsmore et al., 1992; Gillespie and Oliver, 2005; Taponen et al., 2009), can influence 
isolation and identification of bacteria. Further, phenotyping methods are time consuming, have low sensitivity, lack interlaboratory standardization, and are not highly reliable (Pyöralä and Mattila, 1987; Sears et al., 1990; Phuektes et al., 2001; Pitkälä et al., 2005; Suojala et al., 2008), necessitating the development of better tests.

Among the known and potential pathogens that account for most IMI, only a few species of staphylococci predominate (Wilson et al., 1997; Tenhagen et al., 2006). Staphylococci can establish infection rapidly, and frequently persist and remain undetected for long periods particularly in subclinical mastitis. Phenotypic methods remain the gold standard for the identification of staphylococci, and several culture-based systems have been commercialized. However, 30 to $50 \%$ of mastitic milk samples may not show any bacterial growth under conventional culture conditions (Dinsmore et al., 1992; Makovec and Ruegg, 2003; Bradley et al., 2007; Olde Riekerink et al., 2008; Taponen and Pyörälä, 2009). In addition, phenotypic methods have poor discriminatory power, as they frequently misidentify species due to overlapping phenotypes (Renneberg et al., 1995; Rhoden and Miller, 1995; Pitkälä et al., 2005; Zadoks and Watts, 2009).

Polymerase chain reaction analysis has several advantages over phenotypic methods, including (1) direct detection and identification without culturing, (2) rapid turnaround time, (3) high throughput capability, (4) high accuracy, reproducibility, and sensitivity or specificity, and (5) objective user-independent interpretation. Single and multiplex PCR using both end-point and real-time methodologies, either alone or in combination with other techniques, have been applied for the identification of staphylococci to genus and species level, as well as to predict the ability of the organisms to express toxins or virulence determinants or resistance to antibiotics (Mehrotra et al., 2000; Martineau et al., 2001; Strommenger et al., 2003; Tristan et al., 2003; Morot-Bizot et al., 2004; Giammarinaro et al., 2005; Lee et al., 2008; Sasaki et al., 2010; Hirotaki et al., 2011; Shome et al., 2011; Chiang et al., 2012a). Various genes that have been probed either independently or in combination include $16 S$ rRNA, $23 S$ rRNA, clfA, coa, cpn60, femA/B, gap, gla, groESL, hsp60, ITS, nuc, $\operatorname{orf} X, r d r, \operatorname{rpoB}, \operatorname{sod} A$, spa, and tuf, as well as the Sa442 and Se705 fragments (Martineau et al., 1996; 1998Vannuffel et al., 1999; Couto et al., 2001; Mason et al., 2001; Ghebremedhin et al., 2008; Hirotaki et al., 2011; Shome et al., 2011; Chiang et al., 2012a). Several molecular diagnostic kits have also been commercialized.

Staphylococcus aureus is the most important species among the mastitis-associated staphylococci (Jain, 1979; Wilson et al., 1997). This is followed by a group of CNS (Pyörälä and Taponen, 2009), most importantly Staphylococcus epidermidis, in addition to Staphylococcus chromogenes, Staphylococcus simulans, and Staphylococcus hemolyticus. In a recent pilot study, we found that the frequency of isolation of Staph. aureus was more in individual households and that CNS were more frequent in an organized dairy sector in a small region in South India (Hegde et al., 2012). We reasoned that the pathobiology of mastitis caused by Staph. aureus or CNS could be different, and that rapid identification and differentiation of Staph. aureus and Staph. epidermidis could assist in designing of differential intervention strategies. During bioinformatics analyses to develop PCR for simultaneous detection of virulence determinants and differentiation of mastitis-associated Staph. aureus and Staph. epidermidis, we found that the gene encoding the fibrinogen binding protein, fib, can differentiate the 2 species. The development appeared in a single reaction of a multiplex PCR assay for concurrent detection and differentiation of Staph. aureus and Staph. epidermidis. The results indicate that these assays could be adapted for the detection of these organisms in milk.

\section{MATERIALS AND METHODS}

\section{Bioinformatics Analyses}

Complete or partial genomes of Staph. aureus, Staph. epidermidis, Staph. hemolyticus, and Staphylococcus saprophyticus were aligned using ClustalW program (http://www.ebi.ac.uk/Tools/msa/clustalw2/). Unique primers were designed for $f i b$ and thermonuclease $(\boldsymbol{n u c})$ genes using the PrimerQuest program (Integrated DNA Technologies, Coralville, IA).

\section{Bacterial Strains and Biochemical Methods}

All media and reagents for microbiological assays were obtained from HiMedia Laboratories (Mumbai, India). Reference strains of bacteria were obtained from Microbial Type Culture Collection (Chandigarh, India). Field isolates of staphylococci were obtained from clinical and subclinical bovine mastitis samples. Species identification was performed by colony and microscopic morphology, sugar fermentation, and coagulase, phosphatase, and thermonuclease activities (Sundareshan et al., 2012). The identified Staph. aureus and Staph. epidermidis strains were maintained at $-80^{\circ} \mathrm{C}$ in brainheart infusion broth supplemented with $20 \%$ glycerol ( $\mathrm{vol} / \mathrm{vol})$.

\section{Extraction of DNA, Primers, and PCR Conditions}

For routine PCR, bacterial genomic DNA was extracted from overnight culture of a single colony by 
using RealGenomics DNA isolation kit (Real Biotech Corporation, Chennai, India). For limit of detection experiments, $1 \mathrm{~mL}$ of overnight culture was used without dilution or serially diluted 10 -fold to $1 \mathrm{~mL}$ in PBS. Genomic DNA was prepared by heating the culture or diluted sample in boiling water for $10 \mathrm{~min}$, harvesting the supernatant, and extracting the DNA (Rawool et al., 2007). For experiments without or with enrichment, known colony-forming units of bacteria were inoculated into milk or milk plus brain-heart infusion broth (1:1), and DNA was extracted following overnight incubation at $37^{\circ} \mathrm{C}$.

All PCR-related materials, including primers, were obtained from Sigma-Aldrich (Bengaluru, India). Primers were selected based on published information or designed through bioinformatics analyses (Table 1). The PCR was carried out as follows: initial 5-min denaturation step at $94^{\circ} \mathrm{C}$, followed by 30 cycles of $30 \mathrm{~s}$ of denaturation at $94^{\circ} \mathrm{C}, 30 \mathrm{~s}$ of annealing at $60^{\circ} \mathrm{C}$, and 1 min of extension at $72^{\circ} \mathrm{C}$, with a 10 -min final extension at $72^{\circ} \mathrm{C}$. The specificity of each pair of primers was verified by testing against the DNA of standard strains. Multiplex PCR was standardized by varying the combination of primer pairs, annealing temperature, and concentrations of primers, deoxynucleotide triphosphates, and enzyme.

\section{Analytical and Diagnostic Parameters}

Limit of detection (LOD) was determined by serially diluting ( $\log _{10}$-fold) cultures with known counts (cfu) of Staph. aureus or Staph. epidermidis in PBS or pasteurized milk and subjecting to multiplex PCR. The LOD was determined to be the final $\log _{10}$ dilution of the template in which the product was clearly visible after agarose gel electrophoresis.
True and false positives and negatives for the multiplex PCR (test) were deduced by comparison with culture and biochemical identification (standard). Samples corroborating the standard in the positive and negative pool were identified as true, those that did not conform to the results of the standard were identified as false. From the resulting data, the following parameters were calculated as indicated and converted to percentages:

$$
\text { Analytical sensitivity }=\text { LOD, }
$$

Analytical specificity (accuracy) $=$ [no. test positive]/[no. standard positive],

Diagnostic (clinical) sensitivity $=[$ no. true positive $] /$ [no. true positive + no. false negative],

Diagnostic (clinical) specificity $=[$ no. true negative $] /$ [no. true negative + no. false positive],

Positive predictive value $=[$ no. true positive $] /$ [no. true positive + no. false positive],

Negative predictive value $=[$ no. true negative $] /$ [no. true negative + no. false negative].

\section{RESULTS}

\section{Standardization of Simplex PCR}

While comparing 15 Staph. aureus and 2 Staph. epidermidis genomes to select primers for virulence genes,

Table 1. Oligonucleotide primers used in the present study

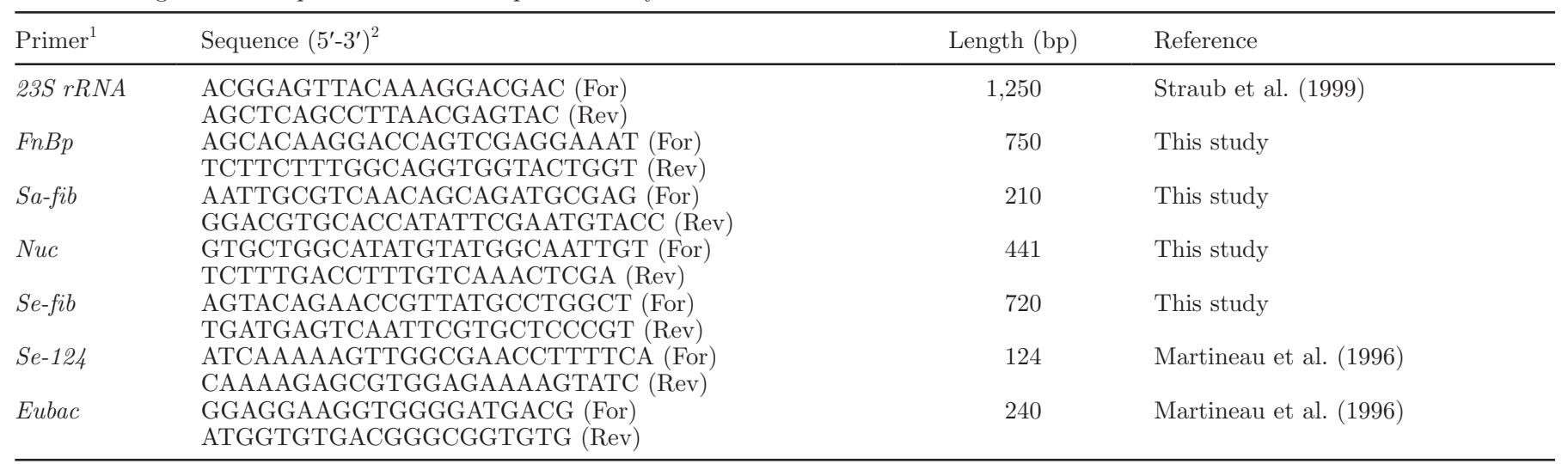

${ }^{1}$ The eubacterial $16 S r R N A$ primers were used separately to confirm the presence of genomic DNA.

${ }^{2}$ For $=$ forward; Rev $=$ reverse. 


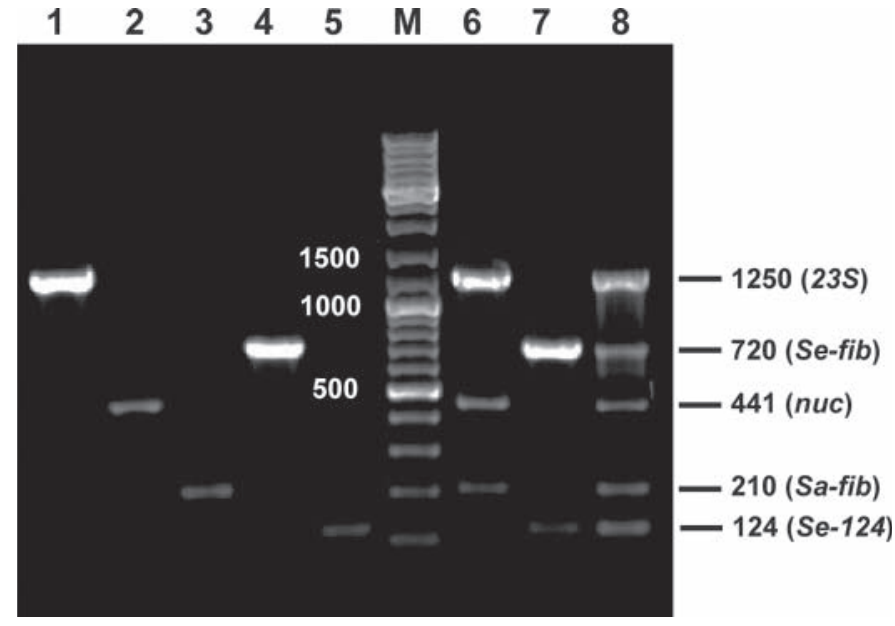

Figure 1. Products amplified by simplex or multiplex PCR on Staphylococcus aureus and Staphylococcus epidermidis isolates were subjected to agarose gel electrophoresis. Lane $1=23 S r R N A$; lane $2=$ $n u c$; lane $3=S a-f i b$; lane $4=S e$-fib; lane $5=S e-124$; lane M $=$ DNA marker; lane $6=$ multiplex PCR of Staph. aureus with $23 S \mathrm{rRNA}$, nuc, and $S a$-fib specific primers; lane $7=$ duplex PCR of Staph. epidermidis with $S e-f i b$ and $S e-124$; and lane $8=$ multiplex PCR with all primers using Staph. aureus and Staph. epidermidis templates.

we identified short stretches within the sequences of $f i b$ to be able to differentiate the two species. Primers for both the species as well as for differing lengths of fibrinogen binding protein $(F n B p)$ and nuc fragments were designed to suit multiplexing (Table 1).

Initial amplification of individual fragments was standardized using reference strains. Fragments of $23 S$ rRNA (1,250 bp), nuc (441 bp), and Sa-fib (200 bp) were observed with Staph. aureus templates, whereas fragments of $S e-f i b(700 \mathrm{bp})$ and $S e-124(124 \mathrm{bp})$ were produced from Staph. epidermidis templates (Figure 1, left of marker). Each amplicon was verified by nucleotide sequencing. Combinations of primer pairs also confirmed the amplification of $23 S r R N A$, nuc, and $S a-f i b$ from Staph. aureus templates, and of Se-fib and Se-124 from Staph. epidermidis templates (Figure 1, right of marker).

\section{Standardization of Multiplex PCR}

The multiplex PCR was optimized to ensure that all the target gene sequences were amplified to a reasonably equivalent extent in a single reaction. However, amplification of $23 S$ rRNA was inhibited whenever primers for $F n B p$ were also used in the same reaction mixture (Table 2). Hence, multiplex PCR was standardized with primers for $S a$-fib (Figure 1), which could differentiate between Staph. aureus and Staph. epidermidis (see Table 3). In addition, the eubacterial $16 S r R N A$ primers inhibited the amplification of not only the species-specific $23 S r R N A$ gene but also that of nuc (Table 2, and data not shown). Therefore, the multiplex PCR included amplification of $23 S r R N A$, nuc, Sa-fib, Se-fib, and Se-124 fragments, whereas the amplification of eubacterial $16 S r R N A$ was performed in a separate tube.

Multiplex PCR was able to detect Staph. aureus or Staph. epidermidis in a mixture of the two. Fragments corresponding to Staph. aureus or Staph. epidermidis were amplified with the triplex or duplex primer pairs, respectively, and a mixture of the templates produced all 5 amplicons (Figure 1, right, and Figure 2, lanes $1-3)$. To verify the suitability of the test in the presence of other organisms, 2 different experiments were performed. First, each CNS and nonstaphylococcal species, as well as Staph. aureus and Staph. epidermidis, were cultured and template-DNA prepared separately, then an equal quantity of each template was mixed together. As expected, when templates from 6 different species of CNS and 5 different species of nonstaphylococci were spiked into the multiplex reaction, no inhibition of amplification of any of the 5 amplicons was observed (data not shown). However, as this does not approximate a mixed infection or culture, a second experiment was

Table 2. Standardization for selection of primers for multiplex PCR

\begin{tabular}{|c|c|c|c|c|c|c|c|c|c|c|c|c|c|}
\hline \multicolumn{7}{|c|}{ Primer combination used } & \multicolumn{7}{|c|}{ Products amplified } \\
\hline $23 S^{1}$ & Nuc & $\mathrm{FnBp}$ & Sa-fib & Se-fib & Se-124 & $\mathrm{E} 16 \mathrm{~S}^{2}$ & $23 \mathrm{~S}$ & Nuc & $\mathrm{FnBp}$ & Sa-fib & Se-fib & Se-124 & E16s \\
\hline+ & & & & & & & + & & & & & & \\
\hline+ & + & & & & & & + & + & & & & & \\
\hline+ & & + & & & & & - & & + & & & & \\
\hline 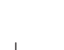 & + & + & & & & & & + & + & & & & \\
\hline+ & + & + & & & & & \pm & + & - & & & & \\
\hline+ & + & & + & & & & + & + & & + & & & \\
\hline+ & + & & + & + & & & + & + & & + & + & & \\
\hline+ & + & & + & + & + & & + & + & & + & + & + & \\
\hline+ & + & & + & + & + & + & - & - & & + & + & + & + \\
\hline
\end{tabular}

${ }^{1} 23 S=23 S r R N A$.

${ }^{2} E 16 S=$ Eukaryotic $16 S r R N A$. 
Table 3. Bacterial strains used and the observed reactivity in PCR for various genes

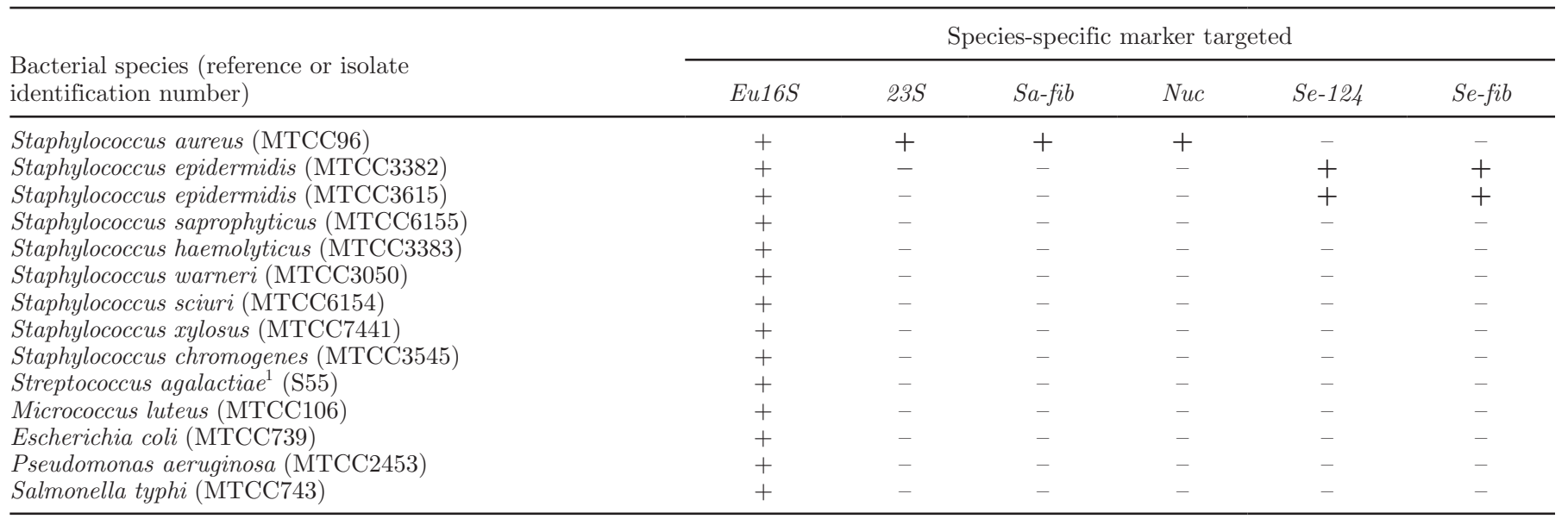

${ }^{1}$ S. agalactiae was isolated from milk sample obtained from a clinical mastitis case.

performed where all CNS and nonstaphylococcal species were cultured in a single tube, with or without Staph. aureus and Staph. epidermidis, and DNA was extracted. Even under these circumstances, no inhibition of amplification was observed (Figure 2, lane 4). The absence of amplification with CNS and nonstaphylococcal species was not attributable to PCR inhibitors or to the inadequacy of the PCR protocol, because the control fragment of $16 S$ rRNA (240 bp) was amplified from all the bacterial species listed in Table 3 , and the results for some of these are shown in Figure 2 (lanes 5-10). Further, the presence of the $16 S r R N A$ fragment in the DNA extracted from individual cultures of Staphylococcus haemolyticus, Staph. saprophyticus, Staph. chromogenes, Escherichia coli, Salmonella typhi, or Streptococcus agalactiae (Figure 2, lanes 5-10), or Staphylococcus warneri, Staphylococcus sciuri, or Staphylococcus xylosus (data not shown), indicated the presence of template DNA in the first set of experiments.

\section{Application of Multiplex PCR to Field Isolates}

To validate the multiplex PCR, the assay was applied to 602 bovine mastitis-associated isolates. These isolates were previously identified as belonging to the Staphylococcus genus and then to a particular species by culturing followed by various biochemical tests, such as sugar fermentation, coagulase activity on rabbit plasma, production of phosphatase, and thermonuclease activity (S. Sundareshan, unpublished data).

Whereas the biochemical method identified 242 isolates as Staph. aureus and 22 isolates as Staph. epidermidis, the respective number of isolates identified by multiplex PCR was 267 and 22 (Table 4). Therefore, the analytical specificity of multiplex PCR was $100 \%$, meaning all the 242 isolates identified by phenotypic method were identified as Staph. aureus by multiplex
PCR. However, multiplex PCR could identify 25 CNS isolates as Staph. aureus. These results show that the multiplex PCR had diagnostic sensitivity and specificity of 100 and $93.5 \%$ for Staph. aureus, and 100 and $100 \%$ for Staph. epidermidis, respectively. The positive and negative predictive values were 90.64 and $100 \%$ for Staph. aureus, and 100 and $100 \%$ for Staph. epidermidis, respectively.

As the multiplex PCR was performed with overnight cultures, which yield abundant bacteria, it was important to compare the different fragments when amplified singly or in the multiplex reaction. The LOD of simplex and multiplex PCR assays were determined with DNA extracted from 10-fold serial dilutions of individual cultures of Staph. aureus and Staph. epidermidis. The detection limit of simplex PCR for Staph. aureus with $23 S$ rRNA was $10^{1} \mathrm{cfu} / \mathrm{mL}$, whereas it was $10^{2} \mathrm{cfu} / \mathrm{mL}$

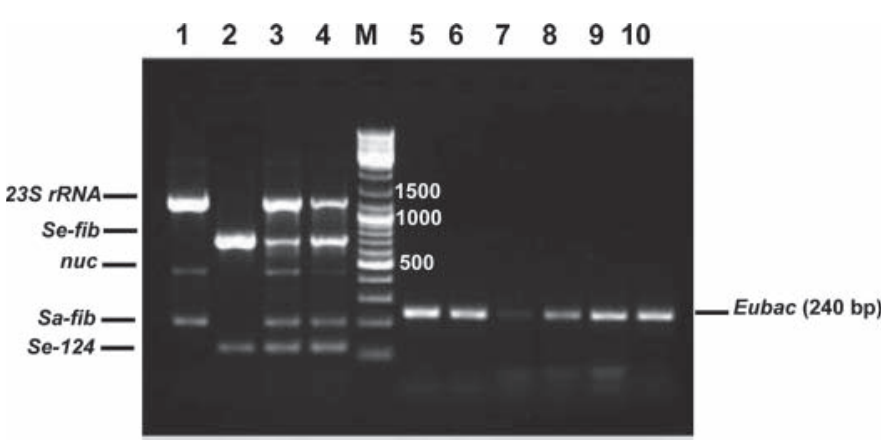

Figure 2. Products amplified by simplex or multiplex PCR on mixed cultures of Staphylococcus aureus and Staphylococcus epidermidis isolates were subjected to agarose gel electrophoresis. Lane $1=$ Staph. aureus; lane $2=$ Staph. epidermidis; lane $3=$ Staph. aureus and Staph. epidermidis; lane $4=$ mixed template of Staph. aureus, Staph. epidermidis, CNS, and nonstaphylococcus species listed in Table 3 ; lane $\mathrm{M}=$ DNA marker; lane $5=$ Staphylococcus hemolyticus; lane 6 $=$ Staphylococcus saprophyticus; lane $7=$ Staphylococcus chromogenes; lane $8=$ Escherichia coli; lane $9=$ Salmonella typh $;$; and lane $10=$ Streptococcus agalactiae. 
Table 4. Comparison of conventional and PCR identification of staphylococci

\begin{tabular}{lc}
\hline Item & No. \\
\hline Staphylococcal isolates tested & 602 \\
CNS & 317 \\
Staph. epidermidis & \\
Biochemical identification & 22 \\
PCR identification & 22 \\
Staph. aureus & \\
Biochemical identification & 242 \\
PCR identification & 267 \\
\hline
\end{tabular}

with $S a-f i b$ and nuc. For Staph. epidermidis, the detection with Se-124 and Se-fib was $10^{1}$ and $10^{2} \mathrm{cfu} / \mathrm{mL}$, respectively. By contrast, the LOD of Staph. aureus and Staph. epidermidis with triplex (23S rRNA, nuc, Sa$f i b)$ or duplex (Se-fib, Se-124) PCR, respectively, was $10^{4} \mathrm{cfu} / \mathrm{mL}$ for each organism when the bacteria were grown overnight in mixed cultures. The detection limit dropped to $10^{6} \mathrm{cfu} / \mathrm{mL}$ for simultaneous detection of Staph. aureus and Staph. epidermidis when all 5 sets of primers were used together (Table 5). To simulate conditions in milk, the LOD studies were repeated using cultures with known counts (cfu) or equivalent DNA diluted in pasteurized milk. The results did not differ from those described above (data not shown). We further investigated whether overnight enrichment culture would enhance the LOD. In these experiments, the analytical sensitivity was observed to be $2 \log _{10}$ better for duplex, triplex or multiplex reactions (Table 5). Thus, the multiplex PCR had an analytical sensitivity of $10^{6} \mathrm{cfu} / \mathrm{mL}$ irrespective of whether buffer or pasteurized milk was used for dilution.

To explore whether the fib gene could be exploited to differentiate other staphylococci, sequences available in GenBank (http://www.ncbi.nlm.nih.gov/genbank/) were aligned along with those of Staph. aureus and Staph. epidermidis. The only fib sequences available were those of Staph. hemolyticus and Staph. saprophyticus; indeed, primers unique to these organisms could be designed (Supplementary Figure S1). Accordingly, PCR would be predicted to amplify unambiguous fragments of 350 and 620 bp for Staph. hemolyticus and Staph. saprophyticus, respectively, which are easily separable from fragments of Staph. aureus (210 bp) and Staph. epidermidis $(720 \mathrm{bp})$ by agarose gel electrophoresis.

\section{DISCUSSION}

Several studies have highlighted the feasibility of using PCR for the detection of bacteria in milk from clinical and subclinical mastitis (Phuektes et al., 2001; Phuektes et al., 2003; Gillespie and Oliver, 2005; Taponen et al., 2009; Koskinen et al., 2010Hirotaki et al., 2011; Shome et al., 2011). Because of the higher frequency of isolation (Thorberg et al., 2006; Oliveira et al., 2006; Shome et al., 2011), Staph. aureus and Staph. epidermidis have been the main organisms targeted for detection (Martineau et al., 1996; 1998; Edwards et al., 2001; Mason et al., 2001; Morot-Bizot et al., 2004; Taponen et al., 2009; Hirotaki et al., 2011; Shome et al., 2011). However, only a few studies have explored the simultaneous detection and differentiation of Staph. aureus and Staph. epidermidis but have targeted different genes in combination, or by using a single gene in real-time PCR assays (Morot-Bizot et al., 2004; Kilic and Basustaoglu, 2011; Shome et al., 2011; Chiang et al., 2012a,b). On the other hand, a few studies have explored the detection of multiple genes within a single species or a group of organisms (Mason et al., 2001; Tristan et al., 2003; Morot-Bizot et al., 2004Cremonesi et al., 2005; Sabat et al., 2006; Jukes et al., 2010; Shome et al., 2011). As deletion in the target region of one gene can produce a false-negative result (Ghebremedhin et al., 2008; Horáková et al., 2008), we attempted a multiplex PCR to detect at least 2 genes in each of Staph. aureus and Staph. epidermidis. Our results show that multiplex PCR using $23 S$ rRNA, nuc, fib, and Se-124 can be used for the identification and differentiation of Staph. aureus and Staph. epidermidis. One must note, however, that mastitis is a consequence of polymicrobial infection and colonization of the mammary gland, and our assay can only detect 2 of the causative agents.

Table 5. Limit of detection (LOD) of simplex and multiplex PCR using mixed culture of Staph. aureus and Staph. epidermidis

\begin{tabular}{|c|c|c|c|c|c|c|}
\hline \multicolumn{5}{|c|}{ Gene fragment amplified } & \multicolumn{2}{|c|}{$\begin{array}{l}\text { Count }(\mathrm{cfu} / \mathrm{mL}) \text { under } \\
\text { indicated culture condition }\end{array}$} \\
\hline $23 S$ & $N u c$ & $S a-f i b$ & Se-124 & $S e-f i b$ & Nonenriched & Enriched \\
\hline \multirow[t]{5}{*}{+} & & & & & $10^{1}$ & $10^{1}$ \\
\hline & + & & & & $10^{2}$ & $10^{2}$ \\
\hline & & + & & & $10^{2}$ & $10^{2}$ \\
\hline & & & + & & $10^{1}$ & $10^{1}$ \\
\hline & & & & + & $10^{2}$ & $10^{2}$ \\
\hline \multirow[t]{2}{*}{+} & + & + & & & $10^{4}$ & $10^{2}$ \\
\hline & & & + & + & $10^{4}$ & $10^{2}$ \\
\hline+ & + & + & + & + & $10^{6}$ & $10^{4}$ \\
\hline
\end{tabular}


The only genes that have been shown so far to differentiate Staph. aureus and Staph. epidermidis by themselves are $16 S$ rRNA, nuc, and femA (Edwards et al., 2001; Jukes et al., 2010; Hirotaki et al., 2011). Whereas differentiation with $16 S$ rRNA (Edwards et al., 2001) and femA (Jukes et al., 2010) was accomplished by melting curve analyses, differentiation with nuc (Hirotaki et al., 2011) was achieved with conventional PCR. In addition, studies with $16 S \mathrm{rRNA}$ and nuc used isolates grown in culture, and did not conduct spiking studies, whereas those with femA applied the test to blood samples. Importantly, none of these groups performed LOD analyses. We have shown that sequences of $f i b$ can also be used to differentiate between the 2 species under a variety of scenarios, including mixed DNA, mixed culture, when spiked into milk, and when spiked and enriched. This is the first and the only colonization-associated gene described so far for the differentiation of Staph. aureus and Staph. epidermidis. In addition, it may also be possible to differentiate Staph. hemolyticus and Staph. saprophyticus, and the availability of complete gene sequences of other CNS may reveal the possibility of differentiating various other species as well.

One could argue that PCR which detects the mere presence of nucleic acids may not be useful to assess bacterial load in milk because even dead and degraded organisms could be detected. Indeed, it is possible that pasteurization will not eliminate DNA, and certain regions of the bacterial genome, particularly those that are thermoresistant, could be amplified by PCR even with a zero total plate count. The pasteurized milk that was used in this study was negative by simplex PCR for both Staph. aureus and Staph. epidermidis (data not shown). As the PCR could detect DNA equivalent to 10 to100 $\mathrm{cfu}$, it is safe to assume that remnants of DNA in pasteurized milk can be ruled out. It is, however, important to perform a quantitative analysis of the detectability of nucleic acid in comparison with cfu. This detailed and complicated analysis was beyond the scope of this study.

The multiplex PCR could identify Staph. aureus and Staph. epidermidis among a mixed culture containing more than a dozen staphylococci and nonstaphylococci. However, these experiments did not analyze competitive growth advantage of any of the organisms, if any exists. It is possible that certain organisms could grow better than others and therefore may reduce the LOD of targeted species. Nonetheless, even though the LOD was lower when mixed cultures were used, it was clear that the LOD was equivalent between Staph. aureus and Staph. epidermidis, suggesting equal growth under mixed culture conditions. The LOD by PCR for Staph. aureus or Staph. epidermidis was $10^{4} \mathrm{cfu} / \mathrm{mL}$, whereas that for simultaneous detection of both the organisms was 100 -fold lower $\left(10^{6} \mathrm{cfu} / \mathrm{mL}\right)$ when mixed templates or cultures were used. This could be attributed to PCR drift or competitive inhibition between primers (Lopes et al., 1999; Hsih and Tsen, 2001; Kösters et al., 2002; Morot-Bizot et al., 2004). Under laboratory conditions, the LOD for staphylococci ranges from $10^{0}$ to $10^{5} \mathrm{cfu} /$ $\mathrm{mL}$. In various clinical specimens, including milk, the LOD ranges from $10^{0}$ to $10^{9} \mathrm{cfu} / \mathrm{mL}$ (Ramesh et al., 2002; Cremonesi et al., 2005; Gillespie and Oliver, 2005; Chiang et al., 2006; 2012a,b; Peles et al., 2007; Lee et al., 2008; Cressier and Bissonnette, 2011; Kilic and Basustaoglu, 2011; Shome et al., 2011). Raw milk obtained from apparently healthy cows has been shown to contain up to $10^{7} \mathrm{cfu} / \mathrm{mL}$ of bacteria (Ramesh et al., 2002; Peles et al., 2007; Dan et al., 2008; Lingathurai and Vellathurai, 2010). It is conceivable that the bacterial load will be much higher, albeit variable, during mastitis. An extrapolation of the results of in vitro testing to milk would be difficult as the biology of the mammary gland and the physicochemical properties of the milk strongly influence microbial growth. In addition, pathogenic bacteria may outgrow nonpathogenic bacteria in vivo because of the virulence factors and invasive strategies utilized by the pathogens. Indeed, staphylococci can account for 50 to $70 \%$ of the microbial load of milk in cases of mastitis (Leonard and Markey, 2008; Lingathurai and Vellathurai, 2010; Mekibib et al., 2010). Thus, it may be possible to apply PCR not just for qualitative diagnosis, but also to evaluate the extent of the microbial load. In this context, advancements such as pit-stop multiplex PCR (Lopes et al., 1999) or real-time PCR could more accurately predict bacterial load once correlations are established.

In our study, 25 clinical isolates that were coagulase negative biochemically (and therefore classified as species other than Staph. aureus) were PCR positive for Staph. aureus markers. On further investigation, these isolates were found by PCR to carry at least a fragment of the coagulase gene (S. Sundareshan, unpublished data). This suggests the coagulase gene is not functional in these 25 isolates. A similar finding of mutated coagulase has been reported (Phonimdaeng et al., 1990). Together with the observations that proper identification of CNS species by phenotypic methods not only requires a combination of phenotypic and molecular assays (Akineden et al., 2011), one could argue that PCR-based assays are more accurate than biochemical assays.

\section{ACKNOWLEDGMENTS}

This work was supported by grants from the Department of Biotechnology, Government of India, to NRH 
and SI (BT/Indo-Aus/04/06/2009), and the Department of Innovation, Industry, Science and Research, Government of Australia, to TKM (BF040038). We thank Rajiv Khanna, Queensland Institute of Medical Research, Australia, for constant encouragement.

\section{REFERENCES}

Akineden, O., A. A. Hassan, E. Schneider, and E. Usleber. 2011. A coagulase-negative variant of Staphylococcus aureus from bovine mastitis milk. J. Dairy Res. 78:38-42.

Bansal, B. K., and D. K. Gupta. 2009. Economic analysis of bovine mastitis in India and Punjab-A review. Indian J. Dairy Sci. $67: 337-345$.

Bradley, A. J., K. A. Leach, J. E. Breen, L. E. Green, and M. J. Green. 2007. Survey of the incidence and aetiology of mastitis on dairy farms in England and Wales. Vet. Rec. 160:253-257.

Chiang, Y. C., L. T. Chang, C. W. Lin, C. Y. Yang, and H. Y. Tsen. 2006. PCR primers for the detection of staphylococcal enterotoxins $\mathrm{K}, \mathrm{L}$, and $\mathrm{M}$ and survey of staphylococcal enterotoxin types in Staphylococcus aureus isolates from food poisoning cases in Taiwan. J. Food Prot. 69:1072-1079.

Chiang, Y. C., H. C. Lu, S. C. Li, Y. H. Chang, H. Y. Chen, C. W. Lin, and H. Y. Tsen. 2012a. Development of PCR primers and a DNA macroarray for the simultaneous detection of major Staphylococcus species using groESL gene. Foodborne Pathog. Dis. 9:249-257.

Chiang, Y. C., H. Y. Tsen, H. Y. Chen, Y. H. Chang, C. K. Lin, C. Y. Chen, and W. Y. Pai. 2012b. Multiplex PCR and a chromogenic DNA macroarray for the detection of Listeria monocytogens, Staphylococcus aureus, Streptococcus agalactiae, Enterobacter sakazakii, Escherichia coli O157:H7, Vibrio parahaemolyticus, Salmonella spp. and Pseudomonas fluorescens in milk and meat samples. J. Microbiol. Methods 88:110-116.

Couto, I., S. Pereira, M. Miragaia, I. S. Sanches, and H. de Lencastre. 2001. Identification of clinical staphylococcal isolates from humans by internal transcribed spacer PCR. J. Clin. Microbiol. 39:3099-3103.

Cremonesi, P., M. Luzzana, M. Brasca, S. Morandi, R. Lodi, C. Vimercati, D. Agnellini, G. Caramenti, P. Moroni, and B. Castiglioni. 2005. Development of a multiplex PCR assay for the identification of Staphylococcus aureus enterotoxigenic strains isolated from milk and dairy products. Mol. Cell. Probes 19:299-305.

Cressier, B., and N. Bissonnette. 2011. Assessment of an extraction protocol to detect the major mastitis-causing pathogens in bovine milk. J. Dairy Sci. 94:2171-2184.

Dan, S. D., M. Mihaiu, O. Rotaru, and I. Dalea. 2008. Evaluation of microbiological load and configuration of raw milk from collecting centres in Cluj county. Bull. USAMV Vet. Med. 65:246-252.

Dinsmore, R. P., P. B. English, R. N. Gonzalez, and P. M. Sears. 1992 Use of augmented cultural techniques in the diagnosis of the bacterial cause of clinical bovine mastitis. J. Dairy Sci. 75:2706-2712.

Edwards, K. J., M. E. Kaufmann, and N. A. Saunders. 2001. Rapid and accurate identification of coagulase-negative staphylococci by real-time PCR. J. Clin. Microbiol. 39:3047-3051.

Ghebremedhin, B., F. Layer, W. Konig, and B. Konig. 2008. Genetic classification and distinguishing of Staphylococcus species based on different partial gap, $16 S \mathrm{rRNA}$, hsp60, rpoB, sodA, and tuf gene sequences. J. Clin. Microbiol. 46:1019-1025.

Giammarinaro, P., S. Leroy, J. P. Chacornac, J. Delmas, and R. Talon. 2005. Development of a new oligonucleotide array to identify staphylococcal strains at species level. J. Clin. Microbiol. 43:3673-3680.

Gillespie, B. E., and S. P. Oliver. 2005. Simultaneous detection of mastitis pathogens, Staphylococcus aureus, Streptococcus uberis, and Streptococcus agalactiae by multiplex real-time polymerase chain reaction. J. Dairy Sci. 88:3510-3518.

Hegde, R., S. Isloor, K. N. Prabhu, B. R. Shome, D. Rathnamma, V V. S. Suryanarayana, S. Yatiraj, C. R. Prasad, N. Krishnaveni, S. Sundareshan, D. S. Akhila, A. R. Gomes, and N. R. Hegde. 2012.
Incidence of subclinical mastitis and prevalence of major mastitis pathogens in organized farms and unorganized sectors. Indian J. Microbiol. http://dx.doi.org/10.1007/s12088-012-0336-1. In press. Hirotaki, S., T. Sasaki, K. Kuwahara-Arai, and K. Hiramatsu. 2011. Rapid and accurate identification of human-associated staphylococci by use of multiplex PCR. J. Clin. Microbiol. 49:3627-3631.

Horáková, K., H. Mlejnkova, and P. Mlejnek. 2008. Evaluation of methods for isolation of DNA for polymerase chain reaction (PCR)-based identification of pathogenic bacteria from pure cultures and water samples. Water Sci. Technol. 58:995-999.

Hsih, H. Y., and H. Y. Tsen. 2001. Combination of immunomagnetic separation and polymerase chain reaction for the simultaneous detection of Listeria monocytogenes and Salmonella spp. in food samples. J. Food Prot. 64:1744-1750.

Jain, N. C. 1979. Common mammary pathogens and factors in infection and mastitis. J. Dairy Sci. 62:128-134.

Jukes, L., J. Mikhail, N. Bome-Mannathoko, S. J. Hadfield, L. G Harris, K. El-Bouri, A. P. Davies, and D. Mack. 2010. Rapid differentiation of Staphylococcus aureus, Staphylococcus epidermidis and other coagulase-negative staphylococci and meticillin susceptibility testing directly from growth-positive blood cultures by multiplex real-time PCR. J. Med. Microbiol. 59:1456-1461.

Kilic, A., and A. C. Basustaoglu. 2011. Double triplex real-time PCR assay for simultaneous detection of Staphylococcus aureus, Staphylococcus epidermidis, Staphylococcus hominis, and Staphylococcus haemolyticus and determination of their methicillin resistance directly from positive blood culture bottles. Res. Microbiol. 162:1060-1066.

Kondo, Y., T. Ito, X. X. Ma, S. Watanabe, B. N. Kreiswirth, J. Etienne, and K. Hiramatsu. 2007. Combination of multiplex PCRs for staphylococcal cassette chromosome mec type assignment: rapid identification system for mec, ccr, and major differences in junkyard regions. Antimicrob. Agents Chemother. 51:264-274.

Koskinen, M. T., G. J. Wellenberg, O. C. Sampimon, J. Holopainen, A. Rothkamp, L. Salmikivi, W. A. van Haeringen, T. J. Lam, and S. Pyorala. 2010. Field comparison of real-time polymerase chain reaction and bacterial culture for identification of bovine mastitis bacteria. J. Dairy Sci. 93:5707-5715.

Kösters, K., U. Reischl, J. Schmetz, M. Riffelmann, and C. H. Wirsing von Konig. 2002. Real-time LightCycler PCR for detection and discrimination of Bordetella pertussis and Bordetella parapertussis. J. Clin. Microbiol. 40:1719-1722.

Lee, K. H., J. W. Lee, S. W. Wang, L. Y. Liu, M. F. Lee, S. T. Chuang, Y. M. Shy, C. L. Chang, M. C. Wu, and C. H. Chi. 2008. Development of a novel biochip for rapid multiplex detection of seven mastitis-causing pathogens in bovine milk samples. J. Vet. Diagn. Invest. 20:463-471.

Leonard, F. C., and B. K. Markey. 2008. Methicillin-resistant Staphylococcus aureus in animals: A review. Vet. J. 175:27-36.

Lingathurai, S., and P. Vellathurai. 2010. Bacteriological quality and safety of raw cow milk in Madurai, South India. WebmedCentral Microbiol. 1:WMC00102.

Lopes, R. F., J. P. Moreno Senna, J. M. Chies, and J. L. Rodrigues. 1999. Pit-stop PCR: An approach to increase final product yield of multiplex PCR. Biotechniques 26:638-639.

Makovec, J. A., and P. L. Ruegg. 2003. Results of milk samples submitted for microbiological examination in Wisconsin from 1994 to 2001. J. Dairy Sci. 86:3466-3472.

Martineau, F., F. J. Picard, D. Ke, S. Paradis, P. H. Roy, M. Ouellette, and M. G. Bergeron. 2001. Development of a PCR assay for identification of staphylococci at genus and species levels. J. Clin. Microbiol. 39:2541-2547.

Martineau, F., F. J. Picard, P. H. Roy, M. Ouellette, and M. G Bergeron. 1996. Species-specific and ubiquitous DNA-based assays for rapid identification of Staphylococcus epidermidis. J. Clin. Microbiol. 34:2888-2893.

Martineau, F., F. J. Picard, P. H. Roy, M. Ouellette, and M. G. Bergeron. 1998. Species-specific and ubiquitous-DNA-based assays for rapid identification of Staphylococcus aureus. J. Clin. Microbiol. 36:618-623. 
Mason, W. J., J. S. Blevins, K. Beenken, N. Wibowo, N. Ojha, and M. S. Smeltzer. 2001. Multiplex PCR protocol for the diagnosis of staphylococcal infection. J. Clin. Microbiol. 39:3332-3338.

Mehrotra, M., G. Wang, and W. M. Johnson. 2000. Multiplex PCR for detection of genes for Staphylococcus aureus enterotoxins, exfoliative toxins, toxic shock syndrome toxin 1 , and methicillin resistance. J. Clin. Microbiol. 38:1032-1035.

Mekibib, B., M. Furgasa, F. Abunna, B. Megersa, and A. Regassa. 2010. Bovine mastitis: Prevalence, risk factors and major pathogens in dairy farms in Holeta town, central Ethiopia. Vet. World 3:397-403.

Morot-Bizot, S. C., R. Talon, and S. Leroy. 2004. Development of a multiplex PCR for the identification of Staphylococcus genus and four staphylococcal species isolated from food. J. Appl. Microbiol. 97:1087-1094.

Oh, M. H., S. H. Paek, G. W. Shin, H. Y. Kim, G. Y. Jung, and S. Oh. 2009. Simultaneous identification of seven foodborne pathogens and Escherichia coli (pathogenic and nonpathogenic) using capillary electrophoresis-based single-strand conformation polymorphism coupled with multiplex PCR. J. Food Prot. 72:1262-1266.

Olde Riekerink, R. G., H. W. Barkema, D. F. Kelton, and D. T. Scholl 2008. Incidence rate of clinical mastitis on Canadian dairy farms. J. Dairy Sci. 91:1366-1377.

Oliveira, M., R. Bexiga, S. F. Nunes, C. Carneiro, L. M. Cavaco, F. Bernardo, and C. L. Vilela. 2006. Biofilm-forming ability profiling of Staphylococcus aureus and Staphylococcus epidermidis mastitis isolates. Vet. Microbiol. 118:133-140.

Peles, F., M. Wagner, L. Varga, I. Hein, P. Rieck, K. Gutser, P. Kereszturi, G. Kardos, I. Turcsanyi, B. Beri, and A. Szabo. 2007. Characterization of Staphylococcus aureus strains isolated from bovine milk in Hungary. Int. J. Food Microbiol. 118:186-193.

Phonimdaeng, P., M. O'Reilly, P. Nowlan, A. J. Bramley, and T. J. Foster. 1990. The coagulase of Staphylococcus aureus 8325-4. Sequence analysis and virulence of site-specific coagulase-deficient mutants. Mol. Microbiol. 4:393-404.

Phuektes, P., G. F. Browning, G. Anderson, and P. D. Mansell. 2003. Multiplex polymerase chain reaction as a mastitis screening test for Staphylococcus aureus, Streptococcus agalactiae, Streptococcus dysgalactiae and Streptococcus uberis in bulk milk samples. J. Dairy Res. 70:149-155.

Phuektes, P., P. D. Mansell, and G. F. Browning. 2001. Multiplex polymerase chain reaction assay for simultaneous detection of Staphylococcus aureus and streptococcal causes of bovine mastitis. J. Dairy Sci. 84:1140-1148.

Pitkälä, A., V. Gindonis, H. Wallin, and T. Honkanen-Buzalski. 2005. Interlaboratory proficiency testing as a tool for improving performance in laboratories diagnosing bovine mastitis. J. Dairy Sci. 88:553-559.

Pyöräla, S., and T. Mattila. 1987. Inflammatory changes during experimental bovine mastitis induced by Staphylococcus aureus, Streptococcus dysgalactiae and Streptococcus uberis. Zentralbl. Veterinarmed. [C] 34:574-581.

Pyörälä, S., and S. Taponen. 2009. Coagulase-negative staphylococciemerging mastitis pathogens. Vet. Microbiol. 134:3-8.

Ramesh, A., B. P. Padmapriya, A. Chrashekar, and M. C. Varadaraj. 2002. Application of a convenient DNA extraction method and multiplex PCR for the direct detection of Staphylococcus aureus and Yersinia enterocolitica in milk samples. Mol. Cell. Probes 16:307-314.

Rawool, D. B., S. V. S. Malik, S. B. Barbuddhe, I. Shakuntala, and R. Aurora. 2007. A multiplex PCR for detection of virulence associated genes in Listeria monocytogenes. Int. J. Food Safety 9:56-62.

Renneberg, J., K. Rieneck, and E. Gutschik. 1995. Evaluation of Staph ID 32 system and Staph-Zym system for identification of coagulase-negative staphylococci. J. Clin. Microbiol. 33:1150-1153.

Rhoden, D. L., and J. M. Miller. 1995. Four-year prospective study of STAPH-IDENT system and conventional method for reference identification of Staphylococcus, Stomatococcus, and Micrococcus spp. J. Clin. Microbiol. 33:96-98.
Sabat, A., N. Malachowa, J. Miedzobrodzki, and W. Hryniewicz. 2006. Comparison of PCR-based methods for typing Staphylococcus aureus isolates. J. Clin. Microbiol. 44:3804-3807.

Sasaki, T., S. Tsubakishita, Y. Tanaka, A. Sakusabe, M. Ohtsuka, S. Hirotaki, T. Kawakami, T. Fukata, and K. Hiramatsu. 2010. Multiplex-PCR method for species identification of coagulase-positive staphylococci. J. Clin. Microbiol. 48:765-769.

Schukken, Y. H., F. J. Grommers, J. A. Smit, D. Vandegeer, and A. Brand. 1989. Effect of freezing on bacteriologic culturing of mastitis milk samples. J. Dairy Sci. 72:1900-1906.

Sears, P. M., B. S. Smith, P. B. English, P. S. Herer, and R. N. Gonzalez. 1990. Shedding pattern of Staphylococcus aureus from bovine intramammary infections. J. Dairy Sci. 73:2785-2789.

Shome, B. R., S. Das Mitra, M. Bhuvana, N. Krithiga, D. Velu, R. Shome, S. Isloor, S. B. Barbuddhe, and H. Rahman. 2011. Multiplex PCR assay for species identification of bovine mastitis pathogens. J. Appl. Microbiol. 111:1349-1356.

Straub, J. A., C. Hertel, and W. P. Hammes. 1999. A 23S rDNAtargeted polymerase chain reaction-based system for detection of Staphylococcus aureus in meat starter cultures and dairy products. J. Food Prot. 62:1150-1156.

Strommenger, B., C. Kettlitz, G. Werner, and W. Witte. 2003. Multiplex PCR assay for simultaneous detection of nine clinically relevant antibiotic resistance genes in Staphylococcus aureus. J. Clin. Microbiol. 41:4089-4094.

Sundareshan, S., Y. Hari Babu, S. Isloor, B. Awati, and N. R. Hegde. 2012. Isolation and phenotype-based speciation of coagulase-negative staphylococci (CoNS) isolated from bovine milk samples. Front. J. Anim. Sci. 1:34-39.

Suojala, L., T. Orro, H. Jarvinen, J. Saatsi, and S. Pyorala. 2008 Acute phase response in two consecutive experimentally induced E. coli intramammary infections in dairy cows. Acta Vet. Scand. 50:18.

Taponen, S., and S. Pyorala. 2009. Coagulase-negative staphylococci as cause of bovine mastitis - not so different from Staphylococcus aureus? Vet. Microbiol. 134:29-36.

Taponen, S., L. Salmikivi, H. Simojoki, M. T. Koskinen, and S. Pyorala. 2009. Real-time polymerase chain reaction-based identification of bacteria in milk samples from bovine clinical mastitis with no growth in conventional culturing. J. Dairy Sci. 92:2610-2617.

Tenhagen, B. A., G. Koster, J. Wallmann, and W. Heuwieser. 2006. Prevalence of mastitis pathogens and their resistance against antimicrobial agents in dairy cows in Brandenburg, Germany. J. Dairy Sci. 89:2542-2551

Thorberg, B. M., I. Kuhn, F. M. Aarestrup, B. Brandstrom, P. Jonsson, and M. L. Danielsson-Tham. 2006. Pheno- and genotyping of Staphylococcus epidermidis isolated from bovine milk and human skin. Vet. Microbiol. 115:163-172.

Tristan, A., L. Ying, M. Bes, J. Etienne, F. Vandenesch, and G. Lina. 2003. Use of multiplex PCR to identify Staphylococcus aureus adhesins involved in human hematogenous infections. J. Clin. Microbiol. 41:4465-4467.

Valvatne, H., M. I. Rijnders, A. Budimir, M. L. Boumans, A. J. de Neeling, P. S. Beisser, E. E. Stobberingh, and R. H. Deurenberg. 2009. A rapid, 2-well, multiplex real-time polymerase chain reaction assay for the detection of SCCmec types I to V in methicillin-resistant Staphylococcus aureus. Diagn. Microbiol. Infect. Dis. 65:384-391.

Vannuffel, P., M. Heusterspreute, M. Bouyer, B. Vandercam, M. Philippe, and J. L. Gala. 1999. Molecular characterization of femA from Staphylococcus hominis and Staphylococcus saprophyticus, and femA-based discrimination of staphylococcal species. Res. Microbiol. 150:129-141.

Wilson, D. J., R. N. Gonzalez, and H. H. Das. 1997. Bovine mastitis pathogens in New York and Pennsylvania: Prevalence and effects on somatic cell count and milk production. J. Dairy Sci. 80:2592-2598.

Zadoks, R. N., and J. L. Watts. 2009. Species identification of coagulase-negative staphylococci: Genotyping is superior to phenotyping. Vet. Microbiol. 134:20-28. 